\title{
PACAP38 and PAC $_{1}$ receptor blockade: a new target for headache?
}

\author{
Eloisa Rubio-Beltrán ${ }^{{ }^{*}}$ (D), Edvige Correnti ${ }^{2}$, Marie Deen ${ }^{3}$, Katharina Kamm $^{4}$, Tim Kelderman $^{5}$, Laura Papetti ${ }^{6}$, \\ Simone Vigneri ${ }^{7}$, Antoinette MaassenVanDenBrink', Lars Edvinsson ${ }^{8}$ and On behalf of the European Headache \\ Federation School of Advanced Studies (EHF-SAS)
}

\begin{abstract}
Pituitary adenylate cyclase activating polypeptide-38 (PACAP38) is a widely distributed neuropeptide involved in neuroprotection, neurodevelopment, nociception and inflammation. Moreover, PACAP38 is a potent inducer of migraine-like attacks, but the mechanism behind this has not been fully elucidated.

Migraine is a neurovascular disorder, recognized as the second most disabling disease. Nevertheless, the antibodies targeting calcitonin gene-related peptide (CGRP) or its receptor are the only prophylactic treatment developed specifically for migraine. These antibodies have displayed positive results in clinical trials, but are not effective for all patients; therefore, new pharmacological targets need to be identified.

Due to the ability of PACAP38 to induce migraine-like attacks, its location in structures previously associated with migraine pathophysiology and the 100-fold selectivity for the $\mathrm{PAC}_{1}$ receptor when compared to VIP, new attention has been drawn to this pathway and its potential role as a novel target for migraine treatment. In accordance with this, antibodies against PACAP38 (ALD 1910) and PAC 1 receptor (AMG 301) are being developed, with AMG 301 already in Phase II clinical trials. No results have been published so far, but in preclinical studies, AMG 301 has shown responses comparable to those observed with triptans. If these antibodies prove to be effective for the treatment of migraine, several considerations should be addressed, for instance, the potential side effects of long-term blockade of the PACAP (receptor) pathway. Moreover, it is important to investigate whether these antibodies will indeed represent a therapeutic advantage for the patients that do not respond the CGRP (receptor)-antibodies.

In conclusion, the data presented in this review indicate that PACAP38 and PAC 1 receptor blockade are promising antimigraine therapies, but results from clinical trials are needed in order to confirm their efficacy and side effect profile.
\end{abstract}

Keywords: PACAP, PAC, receptor, Migraine, Prophylactic treatment

\section{Review}

\section{Discovery of PACAP}

The description of the pituitary adenylate cyclase activating polypeptide-38 (PACAP38) was made by Arimura and his team in 1989, following the extraction of the peptide from more than 4000 samples of ovine hypothalamus. After the isolation, its characterization showed that it was formed by 38 amino acids, with a $68 \%$ homology with vasoactive intestinal peptide (VIP), described almost twenty years earlier [1]. Subsequently, the peptide was synthesized and shown to activate adenylyl cyclase

\footnotetext{
* Correspondence: a.rubiobeltran@erasmusmc.nl

${ }^{1}$ Division of Vascular Medicine and Pharmacology, Department of Internal Medicine, Erasmus University Medical Center, Rotterdam, The Netherlands Full list of author information is available at the end of the article
}

(AC) in cultures of rat pituitary cells, thereby obtaining its name as pituitary adenylate cyclase activating polypeptide. A year later, a fragment of PACAP38 with similar AC activation profile was isolated. This was formed by 27 amino acids and thus named PACAP27 [2]. That same year, cloning of cDNA from ovine PACAP38 revealed that the amino acid sequence of the mature human PACAP38 was identical to that of the ovine. In addition, later studies showed that it was identical in all mammals [3], suggesting that it has been conserved during evolution.

This review will give an overview of PACAP, its complex signaling pathway, the role PACAP and its receptors have in physiological conditions and their involvement in some disorders, with special focus on 
migraine. Moreover, the preclinical results of PACAP (receptor) blockade in migraine models, the side effects that could be expected in clinical trials, and the considerations that must be taken if PACAP (receptor)antibodies are effective for migraine treatment will be discussed.

\section{Pharmacology}

PACAP belongs to a wider group of peptides called the $\mathrm{VIP} /$ glucagon/growth hormone releasing factor/secretin superfamily. The ADCYAP1gene, located on chromosome 18, encodes PACAP; initially, a proprotein is expressed, and later processed to form a 38 amino acid peptide (PACAP38) with a cleavage-amidation site that can generate a 27-residue-amidated fragment (PACAP27). In mammals, the most prevalent form is PACAP38 [4], therefore, in this review PACAP38 will be referred as PACAP unless stated otherwise.

Three PACAP receptors have been described: $\mathrm{VPAC}_{1}$, $\mathrm{VPAC}_{2}$ and $\mathrm{PAC}_{1}$, all coupled to G-proteins (Fig. 1). $\mathrm{VPAC}_{1}$ and $\mathrm{VPAC}_{2}$ receptors present equal affinity for PACAP and VIP and their activation stimulates AC. On the other hand, $\mathrm{PAC}_{1}$ receptor is 100 times more selective for PACAP and presents a complex signaling pathway [4].

Alternative splicing of the $\mathrm{PAC}_{1}$ receptor gene results in several isoforms. These receptor variants are characterized by shorter extracellular domains ( $\mathrm{PAC}_{1}$ short, $\mathrm{PAC}_{1}$ veryshort), different inserts in an intracellular loop important for G-protein interaction ( $\mathrm{PAC}_{1}$ null, $\mathrm{PAC}_{1}$ hip, $\mathrm{PAC}_{1}$ hop1, $\mathrm{PAC}_{1}$ hop2, $\mathrm{PAC}_{1}$ hiphop1, $\mathrm{PAC}_{1}$ hiphop2) and/or discrete sequences located in transmembrane domains II and IV (PAC 1 TM4) [5-8]. Of relevance, in humans, twelve homologues have been reported [7, 911], which have been reviewed elsewhere [12, 13]. For each splice variant, PACAP38 and PACAP27 present similar affinity and potency for $\mathrm{AC}$ and phospholipase $\mathrm{C}$ (PLC) stimulation, but different efficacy (i.e. maximal effect) of PLC responses [14, 15]. Although in several processes the activation of AC or PLC can result in similar "stimulatory" responses, in smooth muscle cells (e.g. blood vessels), activation of AC leads to vasodilation, whereas PLC activation results in vasoconstriction. This plays an important role in disorders such as migraine, where expression of a $\mathrm{PAC}_{1}$ receptor isoform with a lower PLC efficacy could favor AC stimulation, thus facilitating vasodilatory responses in cranial blood vessels $[16,17]$.

To study $\mathrm{PAC}_{1}$ receptor-mediated responses, selective agonists and antagonists are used. Currently, one selective agonist has been described, maxadilan [18, 19] and three antagonists M65, Max.d.4 and PACAP6-38 [20]. However, no study has investigated whether such compounds are selective for one $\mathrm{PAC}_{1}$ receptor variant, or whether they bind to all isoforms. Moreover, PACAP638 also binds to the $\mathrm{VPAC}_{2}$ receptor, and, together with $\mathrm{M} 65$, has been shown to behave as agonist of the $\mathrm{PAC}_{1}$ receptor in certain tissues $[21,22]$. Hence, novel selective pharmacological tools are needed to characterize $\mathrm{PAC}_{1}$ receptor-mediated responses. Indeed, an antibody against the $\mathrm{PAC}_{1}$ receptor, such as $\mathrm{AMG} 301$, could be useful for characterization; however, it is yet not clear

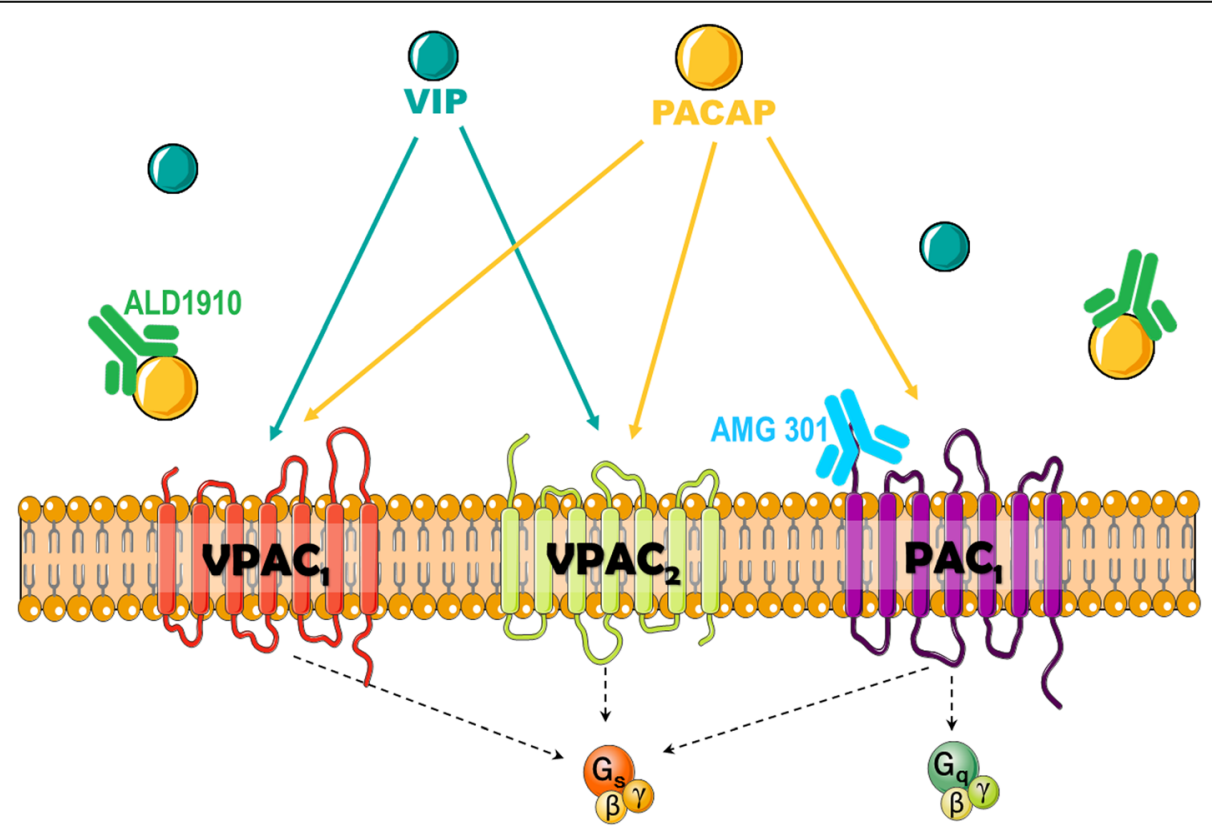

Fig. 1 PACAP receptors. Three receptors to PACAP have been described: VPAC,$V_{1} P C_{2}$ and PAC 1 . VIP and PACAP show similar affinity for VPAC and $\mathrm{VPAC}_{2}$, whereas PACAP is 100-fold more selective for $\mathrm{PAC}_{1}$ receptor. The antibodies developed for prophylactic antimigraine treatment bind either to PACAP (PACAP38, ALD1910) or to the $\mathrm{PAC}_{1}$ receptor (AMG 301) 
wheter this antibody is selective for one specific variant. If the antibody would be selective for one of the splice variants, this may affect its therapeutic potential, in particular if there are different splice variants expressed in different human populations. On the other hand, different splice variants might hypothetically offer the possibility of designing a drug that would selectively affect the $\mathrm{PAC}_{1}$ receptor in the trigeminovascular system, while not affecting $\mathrm{PAC}_{1}$ receptors at other sites in the body, thus reducing its potential side effects.

\section{Physiological roles of PACAP and the $\mathrm{PAC}_{1}$ receptor}

Preclinical studies have shown that PACAP and $\mathrm{PAC}_{1}$ receptors are widely distributed, both centrally and peripherally. It is therefore not surprising that PACAP is described as a (neuro)hormone, neurotransmitter, neuromodulator, neurotrophic factor and immunomodulator [13]. As the $\mathrm{PAC}_{1}$ receptor is currently under investigation for migraine treatment, only the distribution of this receptor will be reviewed, while the distribution of $\mathrm{VPAC}_{1 / 2}$ receptors has been reviewed extensively elsewhere $[13,23,24]$.

\section{PACAP/PAC, receptor in the central nervous system}

PACAP fibers and $\mathrm{PAC}_{1}$ receptors are widely expressed throughout the central nervous system (CNS) with the highest density of both in the hypothalamus and supraoptic nucleus [25-31]. In accordance with this, $\mathrm{PAC}_{1}$ receptor activation has been associated with release of vasopressin and regulation of drinking behavior [32, 33], decrease of food intake [34-36], modulation of the sleep/wake cycle [37, 38], clock gene expression [38], melatonin synthesis stimulation [39], sexual maturation [40, 41], stress and sexual behavior [41, 42], learning [43], pain processing [44] and psychomotor responsiveness [45] .

Of special interest for migraine, both PACAP fibers and the $\mathrm{PAC}_{1}$ receptor are present in the paraventricular nucleus of the hypothalamus, the ventrolateral periaqueductal gray, the locus coeruleus, the solitary nucleus, the trigeminal nucleus caudalis (TNC) and the trigeminal ganglion (TG). These structures have all been associated with nociception and/or migraine pathophysiology [23, 46-49].

\section{PACAP/PAC, receptor in the periphery}

Peripherally, PACAP fibers and/or cell bodies have been described in acrosome caps of primary spermatocytes, mature spermatids, in the testis, epithelial cells from epididymal tubules, the ovaries, mammary glands, in stromal stem cells and terminal placental villi, where the amount of PACAP mRNA increases with the progression of pregnancy [50-52]. Similarly, $\mathrm{PAC}_{1}$ receptors have been described in spermatids, the penile corpus cavernosum, the ovaries, the chorionic vessels and in stromal and decidual cells of the placenta [51, 53-55]. Considering the presence of PACAP and $\mathrm{PAC}_{1}$ receptors also in hypothalamus and pituitary, an important role in modulation of the hypothalamo-pituitary-gonadal axis is suggested.

PACAP fibers and cell bodies are also found in the adrenal gland, pancreas, epithelium and smooth muscle cells of the urinary tract, the bladder, urethra, larynx, lungs, gastrointestinal smooth muscle cells, duodenal mucosa, thymus, spleen and innervating vascular smooth muscle cells [23, 26, 56-67]. PAC 1 receptors have been described in the adrenal medulla, pancreas, liver, lungs, enterochromaffin-like cells, thymus and vascular smooth muscle cells $[47,56,62,67-70]$.

Due to their vast distribution peripherally, PACAP and the $\mathrm{PAC}_{1}$ receptor are involved in a variety of physiological processes, such as regulation of adrenaline release [71], stimulation of adipocyte thermogenesis [72], lipid metabolism [73], metabolic stress adaptation [74], glucose and energy homeostasis [75], renin production $[76,77]$ and inflammatory responses [78]. Furthermore, PACAP and the $\mathrm{PAC}_{1}$ receptor have a crucial role in the long-term maintenance of neurogenic vasodilation in the periphery and in the homeostatic responses to cerebral, retinal, cardiac, hepatic, intestinal and renal ischemic events [79-88]. This topic has been extensively reviewed elsewhere [89].

\section{PACAP and $\mathrm{PAC}_{1}$ receptor in pathophysiological conditions}

Besides being involved in several physiological processes, PACAP is thought to contribute to the pathophysiology of several conditions.

PACAP has been associated with regulation of inflammatory processes. In an arthritis model, $\mathrm{PACAP}^{-/-}$mice showed absence of arthritic hyperalgesia and reduction of joint swelling, vascular leakage and inflammatory cell accumulation. In the late phase of the disease, immune cell function and bone neoformation were increased [90]. In rheumatoid arthritis, the vasodilatory effects of PACAP through activation of the $\mathrm{PAC}_{1}$ receptor facilitated plasma leakage, edema formation, and leukocyte migration $[91,92]$. Furthermore, PACAP $^{-1-}$ mice developed more severe inflammation and tumors in a model of colitis [78]. In preclinical models, upregulation of PACAP and its receptors in micturition pathways contributed to the development of urinary bladder dysfunction, including symptoms of increased voiding frequency and pelvic pain [58], suggesting a role in low urinary tract dysfunction. In the nervous system, studies demonstrated anxiogenic actions of PACAP and the possibility of blocking anxiety-related behaviors with $\mathrm{PAC}_{1}$ receptor antagonists [93-95]. In patients with post-traumatic stress disorder (PTSD), blood levels of PACAP correlated with severity of stress-related symptoms [96], and 
in females, a single nucleotide polymorphism in the estrogen response element of the $\mathrm{PAC}_{1}$ receptor gene is predictive of PTSD diagnosis [97].

Furthermore, PACAP plays a complex role in pain transmission. At the peripheral sensory nerve terminals, pro- and anti-nociceptive effects are observed; while in CNS, central sensitization, increase of neuronal excitation and induction of chronic pain have been described [98]. In an acute somatic and visceral inflammatory model, PACAP decreased pain transmission; however, after application in the spinal cord, a transient induction of analgesia was followed by long-lasting algesia [99]. Moreover, injection of PACAP into the paraventricular nucleus of hypothalamus increased the activity of the $\mathrm{TNC}$, an effect which was inhibited by the $\mathrm{PAC}_{1}$ receptor antagonist [48]. Although it has been shown that PACAP is actively transported through the blood-brain barrier (BBB), it is rapidly degraded or returned by efflux pumps [100]. Thus, a direct central action of peripheral PACAP is unlikely.

Although the role of PACAP in pain processing remains elusive, clinical data strongly suggest the involvement of PACAP in the pathophysiology of migraine and cluster headache $(\mathrm{CH})$ (see also $[101,102])$. Recent evidence of a correlation between a genetic variant of the $\mathrm{PAC}_{1}$ receptor gene (ADCYAP1R1) and susceptibility to $\mathrm{CH}$ was demonstrated [103]. Another study identified a relationship between altered PACAP levels in peripheral blood and different types of headache [104]. Further, two studies reported low interictal plasma levels of PACAP in migraine and $\mathrm{CH}$ when compared to controls [105, 106]. Particularly, a detailed analysis of PACAP mRNA expression in peripheral blood mononuclear cells detected a significantly lower level of PACAP in migraine patients compared to healthy controls, with no significant differences revealed between the control group and tension-type headache, $\mathrm{CH}$ or medication overuse headache groups. Interestingly, PACAP increased ictally in jugular or cubital blood of migraine $[105,107,108]$ and $\mathrm{CH}$ patients $[93,106]$, and levels decreased as headache ameliorated after sumatriptan administration [108]. Finally, when administered to migraine patients, PACAP induced an instant headache in $90 \%$ of patients, which was later followed by a delayed headache similar to a migraine-like attack in two thirds of the subjects [109]. This has led to study the role of PACAP in migraine pathophysiology as will be discussed in the next section.

\section{PACAP in migraine pathophysiology}

The use and development of experimental animal and human models of headache, migraine in particular, have provided invaluable insight into the pathophysiological mechanisms underlying headache disorders $[110,111]$. To investigate the molecular mechanisms behind the headache-inducing effects of PACAP, a number of animal studies have been conducted. Additionally, several human studies have been performed, some of these in combination with imaging techniques. In the following sections, both human and animal studies investigating the headache-related effects of PACAP will be reviewed.

\section{Human studies}

The headache-inducing effect of PACAP was first reported in a study on cerebral blood flow in healthy volunteers, where 10 out of 12 participants reported mild to moderate headache after PACAP infusion [112]. A double-blind, randomized, placebo-controlled, crossover study later showed that 12 out of 12 healthy subjects and 11 out of 12 migraine patients reported headache after intravenous infusion of PACAP, compared to two and three, respectively, after placebo [109]. Further, two healthy subjects and one migraine patient reported a migraine-like attack within $1 \mathrm{~h}$ after infusion, whereas six migraine patients reported a migraine-like attack after a mean of $6 \mathrm{~h}$ (range 2-11 h) after infusion. This study also found dilation of middle cerebral artery (MCA) and the superficial temporal artery after PACAP infusion.

The role of vasodilation in PACAP-induced headache was further explored in a magnetic resonance angiography (MRA) study in healthy volunteers [113]. Eight out of nine participants reported an immediate headache and 100\% reported a delayed headache after PACAP infusion. Further, over a $5 \mathrm{~h}$ period PACAP induced a sustained dilation of the extracranial middle meningeal artery (MMA) but no change in intracerebral MCA. Collectively, these studies support the notion that PACAP induces headache via sustained vasodilation. In another MRA study, PACAP infusion induced headache in $91 \%$ of included migraine patients, and $73 \%$ reported migraine-like attacks compared to $82 \%$ and $18 \%$, respectively, after VIP administration. Further, PACAP induced a long-lasting $(>2 \mathrm{~h})$ dilation of extracranial arteries, whereas the dilation caused by VIP normalized after $2 \mathrm{~h}$. In both cases, dilation of intracranial arteries was not observed. This further underlines prolonged extracranial vasodilation as the migraine inducing mechanism of PACAP [114]. Interestingly, in an in vitro study neither PACAP nor VIP were potent in inducing vasodilation of the intracranial portion of the human MMA [115].

In a resting-state magnetic resonance study, infusion of PACAP affected connectivity in the salience, the default mode and the sensorimotor network during migraine attacks. VIP had no effect on these networks [116]. Another study in migraine patients reproduced the induction of migraine-like attacks in $72 \%$ of patients and showed that PACAP induced premonitory symptoms in $48 \%$ of patients compared to $9 \%$ after CGRP [117], suggesting an effect on central $\mathrm{PAC}_{1}$ receptors. 
However, as described above, PACAP is rapidly degraded or transported back after actively crossing the $\mathrm{BBB}$ [100]; therefore, the premonitory symptoms could be mediated via activation of a central structure that is not protected by the BBB.

Two studies in migraine patients have further analysed plasma levels of markers of peptide release from parasympathetic (VIP) and sensory (CGRP) perivascular nerve fibres; mast cell degranulation (tumour necrosis factor alpha and tryptase); neuronal damage, glial cell activation or leakage of the BBB (S100 calcium binding protein $\mathrm{B}$ and neuron-specific enolase); and hypothalamic activation (prolactin, thyroid-stimulating hormone, follicle-stimulating hormone, luteinizing hormone and adrenocorticotropic hormone) after PACAP infusion $[114,118]$. Only levels of VIP, S100 calcium binding protein $\mathrm{B}$, prolactin and the thyroid-stimulating hormone were modified and did not differ between patients who developed migraine-like attacks and those who did not. However, it is important to consider that samples were obtained from the antecubital vein and it is not known yet if peripheral plasma changes reliably reflect cranial release of mediators.

The human studies point out PACAP as a key player in migraine pathophysiology [102]. As VIP does not induce migraine-like attacks, it is assumed that PACAP's actions are mediated by $\mathrm{PAC}_{1}$ receptor activation. Nevertheless, it is still too early to rule out $\mathrm{VPAC}_{1 / 2}$ receptors as additional potential antimigraine targets, since no studies in humans have been performed with antagonists. Further, the short plasma half-life of VIP, two minutes (as compared to 6-10 min of PACAP [119]), could be the cause of its lack of migraine-inducing effects.

\section{Animal studies}

To characterize the exact receptor involved in PACAP-mediated actions, the vasodilatory effect of PACAP was elucidated in animal studies, showing that VIP, PACAP38 and PACAP27 induce vasodilation of the rat MMA in vivo [120,121]. Interestingly, this effect was blocked by $\mathrm{VPAC}_{1}$ antagonists in the former [120] and $\mathrm{VPAC}_{2}$ antagonists in the latter [121]. Both studies found no effect of $\mathrm{PAC}_{1}$ antagonists on vasodilation. Similarly, in an in vitro study, PACAP induced vasodilation of the human middle meningeal and distal coronary arteries, and this effect was not modified by PACAP638 [115]. In contrast, an ex vivo study found that $\mathrm{PAC}_{1}$ antagonists reversed the PACAP-induced vasodilation in the rat MMA [17]. As mentioned previously, $\mathrm{PAC}_{1}$ receptor antagonists have shown agonistic behavior and affinity for $\mathrm{VPAC}_{2}$ receptors. This could explain the contradictory results observed in the MMA vasodilation studies. Therefore, different methods must be used to elucidate the receptors involved in migraine pathophysiology. For example, in a in vivo model of chronic migraine, induced by recurrent chemical dural stimulation, $\mathrm{PAC}_{1}$ receptor mRNA was shown to be increased in the TG, but not in the TNC, and no significant differences were found in the expression of the $\mathrm{VPAC}_{1}$ and $\mathrm{VPAC}_{2}$ receptors [122]. Moreover, in an in vivo rat model, intravenous administration of AMG 301, the $\mathrm{PAC}_{1}$ receptor antibody, inhibited evoked nociceptive activity in the trigemino-cervical complex, and the results were comparable to the inhibition observed with sumatriptan [123].

In addition to sustained vasodilation, mast cell degranulation has also been suggested as one of the headache-inducing mechanisms of PACAP. This hypothesis is based on findings from animal studies showing that PACAP degranulates mast cells from the rat dura mater [124]. Further, PACAP-induced delayed vasodilation of the rat MMA is attenuated in mast cell depleted rats [125]. Interestingly administration of VIP did not result in mast cell release of histamine from the dura [126]. However, as mentioned previously, no changes in peripheral blood markers of mast cell degranulation have been observed in migraine patients $[114,118]$.

Collectively, the animal studies confirm that PACAP induces vasodilation and suggest that this effect might be mediated through degranulation of mast cells. Also, recent results show that these effects are most likely exerted through activation of the $\mathrm{PAC}_{1}$ receptor. Due to the contradictory results, further studies are warranted to confirm this.

\section{PACAP (receptor) blockade as a therapeutic target}

As shown above, PACAP seems to play an important role in migraine pathophysiology. Although the exact receptor involved has not yet been elucidated, some studies indicate that the $\mathrm{PAC}_{1}$ receptor is the most important [17, 48, 113, 117, 122, 123]. Therefore, both PACAP and $\mathrm{PAC}_{1}$ receptor have been suggested as novel targets for migraine treatment and possibly a new therapeutic option for patients who do not respond to CGRP (receptor) blocking drugs. Although both neuropeptides co-localize in the trigeminal ganglion [49], and could share some biological cascades, the PACAP-induced migraine attacks indicate an independent role of PACAP in the genesis of migraine.

In this light, the interest from pharmaceutical companies for blocking the PACAP/PAC 1 receptor pathway has increased. There are two therapeutic approaches to inhibit PACAP: (i) $\mathrm{PAC}_{1}$ receptor antagonists or antibodies directed against this receptor; or (ii) antibodies directed against the peptide PACAP [102]. Since $\mathrm{PAC}_{1}$ receptor antagonists have been reported to act as agonists depending on the tissue (see Pharmacology), the antibodies seem a better option for blocking this receptor. 
Currently, a phase 2a, randomized, double blind, placebo-controlled study is underway to evaluate the efficacy and safety of a $\mathrm{PAC}_{1}$ receptor antibody (AMG 301 ) in subjects with chronic or episodic migraine (Clinical trials identifier: NCT03238781, [127]). Unfortunately, no preliminary results have been published so far. Preclinical studies are also evaluating a monoclonal antibody (ALD1910) targeting PACAP38 for its potential in the treatment of migraine patients who have an inadequate response to therapeutics directed at CGRP or its receptor [128].

\section{Potential side effects of PACAP/PAC 1 receptor blockade}

Indeed, the possibility of a new therapeutic target for prophylactic migraine treatment is exciting; however, it is important to consider that PACAP and $\mathrm{PAC}_{1}$ receptor participate in numerous physiological processes (see Fig. 2). As antibodies are not likely to cross the BBB, only the possible side effects regarding peripheral blockade of PACAP and $\mathrm{PAC}_{1}$ receptor will be discussed.

As PACAP and $\mathrm{PAC}_{1}$ receptor are expressed throughout the components of the hypothalamo-pituitary-gonadal axis [50-52], and the pituitary gland is not protected by the $\mathrm{BBB}$, a dysregulation of the functions of this axis could be a concern. Also, the immune system has been described to be regulated by activation of $\mathrm{PAC}_{1}$ receptor [61]. This, together with its participation in the modulation of inflammatory processes, could result in alterations in the immune response and increased production of pro-inflammatory cytokines $[78,129]$. In accordance with this, in a mouse model of colitis, PACAP-deficient mice developed a more severe disease [78].

Blocking PACAP might also alter the response to metabolic stress. Studies with PACAP-deficient mice have shown a more profound and longer lasting insulin-induced hypoglycemia and a reduction in glucose-stimulated insulin secretion [74, 75]. Moreover, PACAP-deficient mice had hepatic microvesicular steatosis, intracellular fat accumulation in muscle and skeletal muscle and depletion of subcutaneous white fat [73].

Furthermore, PACAP and the $\mathrm{PAC}_{1}$ receptor participate in vasodilatory responses, renin release and regulation of cardiovascular function [77, 115, 125]. Although the density of $\mathrm{VPAC}_{1 / 2}$ and $\mathrm{PAC}_{1}$ receptors in coronary artery is less than that in cranial MMA [115], arguing for a limited role in cardiac ischemia, a protective role in ischemic events has been described. Thus, considering the increased cardiovascular risk that migraine patients present [130-133], careful monitoring of patients with preexisting cardiovascular risk factors is advised. However, similar concerns have been raised with the CGRP (receptor)-antibodies [134, 135], with no cardiovascular adverse events reported in the clinical trials [136].

\section{Further considerations}

If the antibodies against the $\mathrm{PAC}_{1}$ receptor prove to be effective for the prophylactic treatment of migraine, some concerns should be addressed. Firstly, as previously discussed, it is important to consider the possible side effects of long-term blockade of PACAP/PAC 1

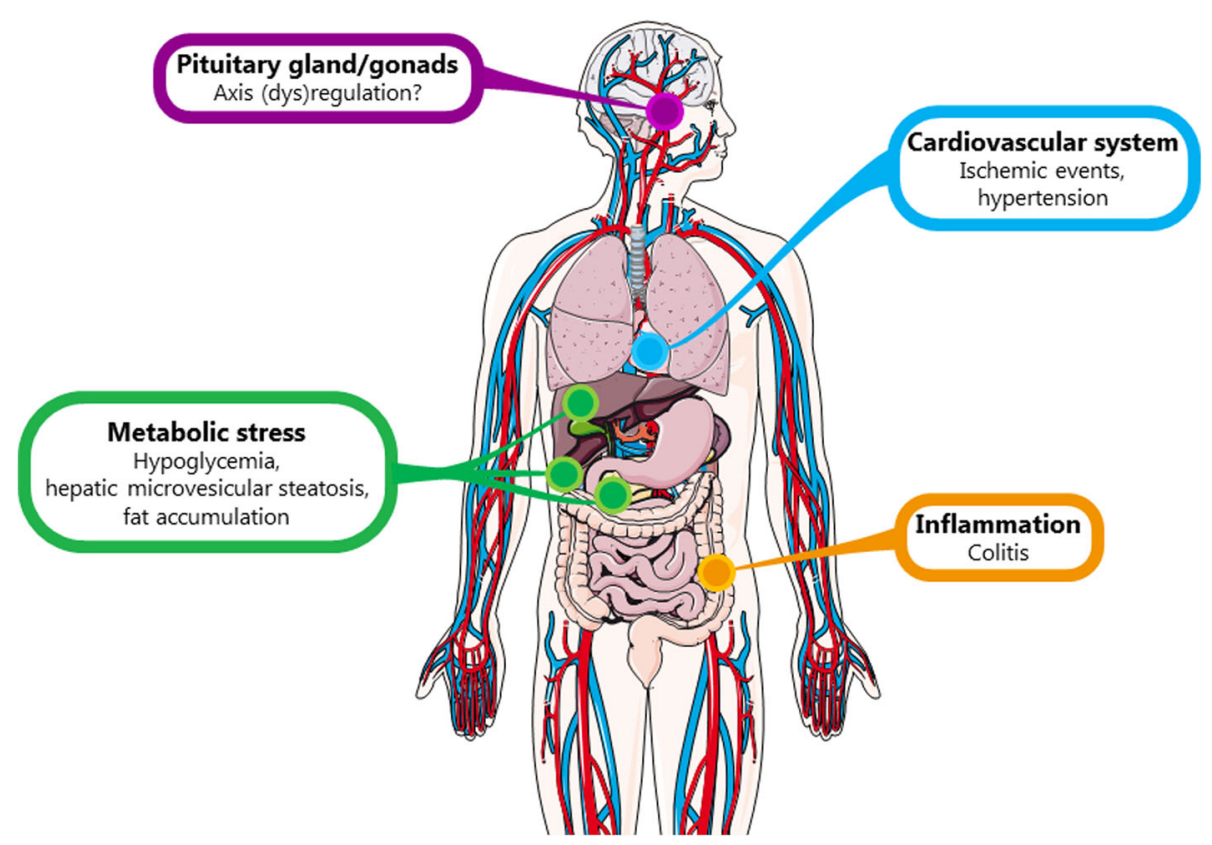

Fig. 2 Possible side effects after long-term exposure to PACAP (receptor)-antibodies. An overview of the organ systems where PACAP and PAC 1 receptor are present and the possible side effects that could be observed 
receptor, with emphasis on the cardiovascular system, as migraine patients present a higher cardiovascular risk. Therefore, safety studies in patients with cardiovascular disease are needed. Moreover, the administration route of the antibody against the $\mathrm{PAC}_{1}$ receptor is subcutaneous, thus erythema, pruritus and mild pain in the injection site could be expected, as it has been observed with the CGRP (receptor) - antibodies [136]. Nevertheless, the monthly administration represents an advantage for treatment adherence.

It will also be important to define whether $\mathrm{PAC}_{1}$ receptor antibodies will really represent a therapeutic advantage for the patients that are not responding to the CGRP (receptor)-antibodies. Since studies have shown that PACAP and CGRP co-localize in structures relevant for migraine pathophysiology (e.g. trigeminal ganglion) [49], PACAP blockade may only be effective for the same patients to whom CGRP blockade is already effective. If a distinction can be made between patient groups this would also shed light on the pathophysiology of migraine, as it could distinguish between CGRP-associated or PACAP-associated migraine patients. Moreover, the $\mathrm{PAC}_{1}$ receptor sequence that is recognized by the antibody has not been disclosed, thus, the variants of the receptor to which the antibody binds are not known. If revealed, it would be interesting to study whether certain receptor isoforms predispose patients to present $\mathrm{mi}$ graine, or whether the treatment will only be effective in patients with those isoforms.

Finally, as mentioned previously, it is still too early to rule out $\mathrm{VPAC}_{1 / 2}$ receptors as therapeutic targets for migraine treatment. Therefore, ALD1910, the antibody against PACAP38, currently undergoing preclinical studies [128], broadens the therapeutic options for migraine treatment. However, further safety studies should be addressed, as blocking PACAP38 would inhibit the actions of three different receptors, increasing the possibilities of adverse side effects.

\section{Conclusion}

The possible role of PACAP/PAC 1 receptor blockade as migraine treatment has been reviewed. All three PACAP receptors have been described in TG, TNC and (dural) arteries, structures previously related to migraine pathophysiology $[47,49]$. Indeed, infusion of PACAP is able to induce migraine-like attacks [109]. Moreover, interictally, low plasma levels of PACAP have been described [105], while during a migraine attack, PACAP increases in jugular and cubital blood $[105,108]$ and decreases as headache ameliorates after sumatriptan administration [108].

Clinical studies have shown that infusion of VIP does not induce migraine-like headaches [114], therefore, it is considered that the possible receptor involved in PACAP actions is $\mathrm{PAC}_{1}$ receptor, as VIP has affinity for $\mathrm{VPAC}_{1}$ and $\mathrm{VPAC}_{2}$ receptors; although this could be attributed to pharmacokinetic (i.e. half-life), rather than pharmacodynamic aspects. Pharmacological characterization in preclinical studies has provided contradictory results, indicating a complex pharmacology of the $\mathrm{PAC}_{1}$ receptor $[21,22]$. However, a recent in vivo study showed that intravenous infusion of $\mathrm{PAC}_{1}$ receptor antibody, inhibited evoked nociceptive activity in the trigemino-cervical complex in rats, and these results were comparable to the inhibition observed with sumatriptan [123]. These results have led to the development of antibodies against PACAP (ALD1910) and $\mathrm{PAC}_{1}$ receptor (AMG 301) for migraine treatment.

In conclusion, the data presented in this review indicate that PACAP and $\mathrm{PAC}_{1}$ receptor blockade are promising migraine therapies but results from clinical trials are needed in order to confirm their efficacy and their side effects profile.

\section{Abbreviations}

AC: Adenylyl cyclase; BBB: Blood-brain barrier; CGRP: Calcitonin gene-related peptide; CH: Cluster headache; CNS: Central nervous system; MCA: Middle cerebral artery; MMA: Middle meningeal artery; MRA: Magnetic resonance angiography; PACAP38: Pituitary adenylate cyclase activating polypeptide-38; PLC: Phospholipase C; PTSD: Post-traumatic stress disorder; TG: Trigeminal ganglion; TNC: Trigeminal nucleus caudalis; VIP: Vasoactive intestinal peptide

\section{Acknowledgements}

The European Headache Federation and the Department of Clinical and Molecular Medicine, Sapienza University of Rome, are gratefully acknowledged for supporting this work. Figs. 1 and 2 were modified from Servier Medical Art, licensed under a Creative Common Attribution 3.0 Generic License, https://smart.servier.com/.

\section{Funding}

This work was supported by the European Headache Federation.

\section{Authors' contributions}

$A M v d B$ and $L E$ conceived the review. All authors designed the review, drafted the manuscript and revised it for intellectual content. All authors read and approved the final manuscript.

Ethics approval and consent to participate

Not applicable.

\section{Consent for publication}

Not applicable.

\section{Competing interests}

AMvdB received research grants and/or consultation fees from Amgen/ Novartis, Lilly/CoLucid, Teva and ATI. LE has given talks and received grant for preclinical studies sponsored by Novartis and TEVA. All other authors declare no conflicts of interest.

\section{Publisher's Note}

Springer Nature remains neutral with regard to jurisdictional claims in published maps and institutional affiliations.

\section{Author details}

'Division of Vascular Medicine and Pharmacology, Department of Internal Medicine, Erasmus University Medical Center, Rotterdam, The Netherlands. ${ }^{2}$ Department of Child Neuropsychiatry, University of Palermo, Palermo, Italy. ${ }^{3}$ Danish Headache Center, Department of Neurology, Rigshospitalet Glostrup, Glostrup, Denmark. ${ }^{4}$ Department of Neurology, University Hospital, LMU 
Munich, Munich, Germany. ${ }^{5}$ Department of Neurology, Ghent University Hospital, Ghent, Belgium. 'Headache Center, Bambino Gesù Children's Hospital, IRCCS, Rome, Italy. ${ }^{7}$ Department of Experimental Biomedicine and Clinical Neurosciences, University of Palermo; Pain Medicine Unit, Santa Maria Maddalena Hospital, Occhiobello, Italy. ${ }^{8}$ Department of Internal Medicine, Institute of Clinical Sciences, Lund University, Lund, Sweden.

\section{Received: 5 June 2018 Accepted: 24 July 2018}

Published online: 07 August 2018

\section{References}

1. Miyata A, Arimura A, Dahl RR, Minamino N, Uehara A, Jiang L, Culler MD, Coy DH (1989) Isolation of a novel 38 residue-hypothalamic polypeptide which stimulates adenylate cyclase in pituitary cells. Biochem Biophys Res Commun 164(1):567-574 https://doi.org/10.1016/0006-291X(89)91757-9

2. Miyata A, Jiang L, Dahl RD, Kitada C, Kubo K, Fujino M, Minamino N, Arimura A (1990) Isolation of a neuropeptide corresponding to the N-terminal 27 residues of the pituitary adenylate cyclase activating polypeptide with 38 residues (PACAP38). Biochem Biophys Res Commun 170(2):643-648 https:// doi.org/10.1016/0006-291X(90)92140-U

3. Kimura C, Ohkubo S, Ogi K, Hosoya M, Itoh Y, Onda H, Miyata A, Jiang L, Dahl RR, Stibbs HH, Arimura A, Fujino M (1990) A novel peptide which stimulates adenylate cyclase: molecular cloning and characterization of the ovine and human cDNAs. Biochem Biophys Res Commun 166(1):81-89 https://doi.org/10.1016/0006-291X(90)91914-E

4. Harmar AJ, Fahrenkrug J, Gozes I, Laburthe M, May V, Pisegna JR, Vaudry D, Vaudry H, Waschek JA, Said SI (2012) Pharmacology and functions of receptors for vasoactive intestinal peptide and pituitary adenylate cyclaseactivating polypeptide: IUPHAR review 1. Br J Pharmacol 166(1):4-17. https://doi.org/10.1111/j.1476-5381.2012.01871.x

5. Shinohara K, Funabashi T, Nakamura TJ, Mitsushima D, Kimura F (2002) Differential regulation of pituitary adenylate cyclase-activating peptide receptor variants in the rat suprachiasmatic nucleus. Neuroscience 110(2): 301-308 https://doi.org/10.1016/S0306-4522(01)00479-1

6. Joumot L, Waeber C, Pantaloni C, Holsboer F, Seeburg PH, Bockaert J, Spengler D (1995) Differential signal transduction by six splice variants of the pituitary adenylate cyclase-activating peptide (PACAP) receptor. Biochem Soc Trans 23(1):133-137. https://doi.org/10.1042/bst0230133

7. Pantaloni C, Brabet P, Bilanges B, Dumuis A, Houssami S, Spengler D, Bockaert J, Journot L (1996) Alternative splicing in the N-terminal extracellular domain of the pituitary adenylate cyclase-activating polypeptide (PACAP) receptor modulates receptor selectivity and relative potencies of PACAP-27 and PACAP-38 in phospholipase C activation. J Biol Chem 271(36):22146-22151. https://doi.org/10.1074/jbc.271.36.22146

8. Chatterjee TK, Sharma RV, Fisher RA (1996) Molecular cloning of a novel variant of the pituitary adenylate cyclase-activating polypeptide (PACAP) receptor that stimulates calcium influx by activation of L-type calcium channels. J Biol Chem 271(50):32226-32232. https://doi.org/10.1074/jbc.271.50.32226

9. Lutz EM, Ronaldson E, Shaw P, Johnson MS, Holland PJ, Mitchell R (2006) Characterization of novel splice variants of the $P A C_{1}$ receptor in human neuroblastoma cells: consequences for signaling by VIP and PACAP. Mol Cell Neurosci 31(2):193-209 https://doi.org/10.1016/j.mcn.2005.09.008

10. Dautzenberg FM, Mevenkamp G, Wille S, Hauger RL (1999) N-terminal splice variants of the type I PACAP receptor: isolation, characterization and ligand binding/selectivity determinants. J Neuroendocrinol 11(12):941-949. https:// doi.org/10.1046/j.1365-2826.1999.00411.x

11. Pisegna JR, Wank SA (1996) Cloning and characterization of the signal transduction of four splice variants of the human pituitary adenylate cyclase activating polypeptide receptor: evidence for dual coupling to adenylate cyclase and phospholipase C. J Biol Chem 271(29):17267-17274. https://doi. org/10.1074/jbc.271.29.17267

12. Blechman J, Levkowitz G (2013) Alternative splicing of the pituitary adenylate cyclase-activating polypeptide receptor $\mathrm{PAC}_{1}$ : mechanisms of fine tuning of brain activity. Front Endocrinol 4(55):1-19

13. Dickson L, Finlayson K (2009) VPAC and PAC receptors: from ligands to function. Pharmacol Ther 121(3):294-316 https://doi.org/10.1016/j. pharmthera.2008.11.006

14. Spengler D, Waeber C, Pantaloni C, Holsboer F, Bockaert J, Seeburgt PH, Journot L (1993) Differential signal transduction by five splice variants of the PACAP receptor. Nature 365:170. https://doi.org/10.1038/365170a0
15. Braas KM, May V (1999) Pituitary adenylate cyclase-activating polypeptides directly stimulate sympathetic neuron neuropeptide $Y$ release through $P A C_{1}$ receptor isoform activation of specific intracellular signaling pathways. J Biol Chem 274(39):27702-27710. https://doi.org/10.1074/jbc.274.39.27702

16. Erdling A, Sheykhzade M, Maddahi A, Bari F, Edvinsson L (2013) VIP/PACAP receptors in cerebral arteries of rat: characterization, localization and relation to intracellular calcium. Neuropeptides 47(2):85-92. https://doi.org/10.1016/j.npep. 2012.12.005

17. Syed AU, Koide M, Braas KM, May V, Wellman GC (2012) Pituitary adenylate cyclase-activating polypeptide (PACAP) potently dilates middle meningeal arteries: implications for migraine. J Mol Neurosci 48(3):574-583. https://doi. org/10.1007/s12031-012-9851-0

18. Moro O, Lerner EA (1997) Maxadilan, the vasodilator from sand flies, is a specific pituitary adenylate cyclase activating peptide type I receptor agonist. J Biol Chem 272(2):966-970. https://doi.org/10.1074/jbc.272.2.966

19. Tatsuno I, Uchida D, Tanaka T, Saeki N, Hirai A, Saito Y, Moro O, Tajima M (2001) Maxadilan specifically interacts with PAC1 receptor, which is a dominant form of PACAPNIP family receptors in cultured rat cortical neurons. Brain Res 889(1):138-148 https://doi.org/10.1016/S00068993(00)03126-7

20. Uchida D, Tatsuno I, Tanaka T, Hirai A, Saito Y, Moro O, Tajima M (1998) Maxadilan is a specific agonist and its deleted peptide (M65) is a specific antagonist for PACAP type 1 receptor. Ann N Y Acad Sci 865(1):253-258. https://doi.org/10.1111/j.1749-6632.1998.tb11185.x

21. Sághy É, Payrits M, Helyes Z, Reglődi D, Bánki E, Tóth G, Couvineau A, Szőke É (2015) Stimulatory effect of pituitary adenylate cyclase-activating polypeptide 638, M65 and vasoactive intestinal polypeptide 6-28 on trigeminal sensory neurons. Neuroscience 308:144-156 https://doi.org/10.1016/j.neuroscience.2015. 08.043

22. Reglodi D, Borzsei R, Bagoly T, Boronkai A, Racz B, Tamas A, Kiss P, Horvath G, Brubel R, Nemeth J, Toth G, Helyes Z (2008) Agonistic behavior of PACAP6-38 on sensory nerve terminals and Cytotrophoblast cells. J Mol Neurosci 36(1):270-278. https://doi.org/10.1007/s12031-008-9089-z

23. Vaudry D, Falluel-Morel A, Bourgault S, Basille M, Burel D, Wurtz O, Fournier A, Chow BKC, Hashimoto H, Galas L, Vaudry H (2009) Pituitary adenylate cyclase-activating polypeptide and its receptors: 20 years after the discovery. Pharmacol Rev 61(3):283-357. https://doi.org/10. 1124/pr.109.001370

24. Sherwood NM, Krueckl SL, McRory JE (2000) The origin and function of the pituitary adenylate cyclase-activating polypeptide (PACAP)/glucagon superfamily*. Endocr Rev 21(6):619-670

25. Köves K, Arimura A, Görcs TG, Somogyvári-Vigh A (1991) Comparative distribution of Immunoreactive pituitary adenylate cyclase activating polypeptide and vasoactive intestinal polypeptide in rat forebrain. Neuroendocrinology 54(2):159-169

26. Kóves K, Arimura A, Somogyvári-Vigh A, Vigh S, Miller JIM (1990) Immunohistochemical demonstration of a novel hypothalamic peptide, pituitary adenylate cyclase-activating polypeptide, in the ovine hypothalamus*. Endocrinology 127(1):264-271

27. Hannibal J (2002) Pituitary adenylate cyclase-activating peptide in the rat central nervous system: an immunohistochemical and in situ hybridization study. J Comp Neurol 453(4):389-417. https://doi.org/10.1002/cne.10418

28. Kivipelto L, Absood A, Arimura A, Sundler F, Håkanson R, Panula P (1992) The distribution of pituitary adenylate cyclase-activating polypeptide-like immunoreactivity is distinct from helodermin- and helospectin-like immunoreactivities in the rat brain. J Chem Neuroanat 5(1):85-94 https:// doi.org/10.1016/0891-0618(92)90036-P

29. Joo KM, Chung YH, Kim MK, Nam RH, Lee BL, Lee KH, Cha Cl (2004) Distribution of vasoactive intestinal peptide and pituitary adenylate cyclaseactivating polypeptide receptors $\left(\mathrm{VPAC}_{1}, \mathrm{VPAC}_{2}\right.$, and $P A C_{1}$ receptor) in the rat brain. J Comp Neurol 476(4):388-413. https://doi.org/10.1002/cne.20231

30. Mikkelsen JD, Hannibal J, Larsen PJ, Fahrenkrug J (1994) Pituitary adenylate cyclase activating peptide (PACAP) mRNA in the rat neocortex. Neurosci Lett 171(1):121-124 https://doi.org/10.1016/0304-3940(94)90620-3

31. Suda K, Smith DM, Ghatei MA, Murphy JK, Bloom SR (1991) Investigation and characterization of receptors for pituitary adenylate cyclase-activating polypeptide in human brain by Radioligand binding and chemical crosslinking. J Clin Endocrinol Metabol 72(5):958-964

32. Kageyama K, Hanada K, Iwasaki Y, Sakihara S, Nigawara T, Kasckow J, Suda T (2007) Pituitary adenylate cyclase-activating polypeptide stimulates corticotropin-releasing factor, vasopressin and interleukin-6 gene 
transcription in hypothalamic 4B cells. J Endocrinol 195(2):199-211. https:// doi.org/10.1677/joe-07-0125

33. Nomura M, Ueta Y, Larsen PJ, Hannibal J, Serino R, Kabashima N, Shibuya I, Yamashita H (1997) Water deprivation increases the expression of pituitary adenylate cyclase-activating polypeptide gene in the rat Subfornical organ*. Endocrinology 138(10):4096-4100

34. Mizuno Y, Kondo K, Terashima Y, Arima H, Murase T, Oiso Y (1998) Anorectic effect of pituitary adenylate cyclase activating polypeptide (PACAP) in rats: lack of evidence for involvement of hypothalamic neuropeptide gene expression. J Neuroendocrinol 10(8):611-616. https://doi.org/10.1046/j.13652826.1998.00244.x

35. Mounien L, Bizet P, Boutelet I, Gourcerol G, Fournier A, Vaudry H, Jégou S (2006) Pituitary adenylate cyclase-activating polypeptide directly modulates the activity of proopiomelanocortin neurons in the rat arcuate nucleus. Neuroscience 143(1): 155-163 https://doi.org/10.1016/j.neuroscience.2006.07.022

36. Mounien L, Do Rego J-C, Bizet P, Boutelet I, Gourcerol G, Fournier A, Brabet P, Costentin J, Vaudry H, Jégou S (2008) Pituitary adenylate cyclaseactivating polypeptide inhibits food intake in mice through activation of the hypothalamic Melanocortin system. Neuropsychopharmacology 34:424. https://doi.org/10.1038/npp.2008.73

37. Kawaguchi C, Tanaka K, Isojima Y, Shintani N, Hashimoto H, Baba A, Nagai K (2003) Changes in light-induced phase shift of circadian rhythm in mice lacking PACAP. Biochem Biophys Res Commun 310(1):169-175 https://doi. org/10.1016/j.bbrc.2003.09.004

38. Hannibal J, Fahrenkrug J (2004) Target areas innervated by PACAPimmunoreactive retinal ganglion cells. Cell Tissue Res 316(1):99-113. https:// doi.org/10.1007/s00441-004-0858-x

39. Hannibal J, Jamen F, Nielsen HS, Journot L, Brabet P, Fahrenkrug J (2001) Dissociation between light-induced phase shift of the circadian rhythm and clock gene expression in mice lacking the pituitary adenylate cyclase activating polypeptide type 1 receptor. J Neurosci 21(13):4883-4890

40. Apostolakis EM, Riherd DN, O'Malley BW (2005) PAC 1 receptors mediate pituitary adenylate cyclase-activating polypeptide- and progesteronefacilitated receptivity in female rats. Mol Endocrinol 19(11):2798-2811

41. Shintani N, Mori W, Hashimoto H, Imai M, Tanaka K, Tomimoto S, Hirose M, Kawaguchi C, Baba A (2002) Defects in reproductive functions in PACAPdeficient female mice. Regul Pept 109(1):45-48 https://doi.org/10.1016/ S0167-0115(02)00169-6

42. Amir-Zilberstein L, Blechman J, Sztainberg Y, Norton William HJ, Reuveny A, Borodovsky N, Tahor M, Bonkowsky Joshua L, Bally-Cuif L, Chen A, Levkowitz G (2012) Homeodomain protein Otp and activity-dependent splicing modulate neuronal adaptation to stress. Neuron 73(2):279-291 https://doi.org/10.1016/j.neuron.2011.11.019

43. Otto C, Kovalchuk Y, Wolfer DP, Gass P, Martin M, Zuschratter W, Gröne HJ, Kellendonk C, Tronche F, Maldonado R, Lipp H-P, Konnerth A, Schütz G (2001) Impairment of mossy Fiber long-term potentiation and associative learning in pituitary adenylate cyclase activating polypeptide type I receptor-deficient mice. J Neurosci 21(15):5520-5527. https://doi.org/10. 1523/jneurosci.21-15-05520.2001

44. Ohnou T, Yokai M, Kurihara T, Hasegawa-Moriyama M, Shimizu T, Inoue K, Kambe Y, Kanmura Y, Miyata A (2016) Pituitary adenylate cyclase-activating polypeptide type 1 receptor signaling evokes long-lasting nociceptive behaviors through the activation of spinal astrocytes in mice. J Pharmacol Sci 130(4):194-203 https://doi.org/10.1016/j.jphs.2016.01.008

45. Hashimoto H, Shintani N, Tanaka K, Mori W, Hirose M, Matsuda T, Sakaue M, J-i M, Niwa H, Tashiro F, Yamamoto K, Koga K, Tomimoto S, Kunugi A, Suetake S, Baba A (2001) Altered psychomotor behaviors in mice lacking pituitary adenylate cyclase-activating polypeptide (PACAP). Proc Natl Acad Sci 98(23):13355-13360. https://doi.org/10.1073/pnas.231094498

46. Tajti J, Uddman R, Edvinsson L (2001) Neuropeptide localization in the 'migraine generator' region of the human brainstem. Cephalalgia 21(2):96101. https://doi.org/10.1046/j.1468-2982.2001.00140.x

47. Knutsson M, Edvinsson $L$ (2002) Distribution of mRNA for VIP and PACAP receptors in human cerebral arteries and cranial ganglia. NeuroReport 13(4): 507-509

48. Robert C, Bourgeais L, Arreto CD, Condes-Lara M, Noseda R, Jay T, Villanueva $L$ (2013) Paraventricular hypothalamic regulation of trigeminovascular mechanisms involved in headaches. J Neurosci 33(20):8827-8840. https:// doi.org/10.1523/JNEUROSCI.0439-13.2013

49. Eftekhari S, Salvatore CA, Johansson S, Chen TB, Zeng Z, Edvinsson L (2015) Localization of CGRP, CGRP receptor, PACAP and glutamate in trigeminal ganglion. Relation to the blood-brain barrier. Brain Res 1600:93-109. https:// doi.org/10.1016/j.brainres.2014.11.031

50. Koh P-O, Won C-K, Noh H-S, Cho G-J, Choi W-S (2005) Expression of pituitary adenylate cyclase activating polypeptide and its type I receptor mRNAs in human placenta. J Vet Sci 6(1):1-5

51. Scaldaferri ML, Modesti A, Palumbo C, Ulisse S, Fabbri A, Piccione E, Frajese G, Moretti C (2000) Pituitary adenylate cyclase-activating polypeptide (PACAP) and PACAP-receptor type 1 expression in rat and human placenta* Endocrinology 141(3):1158-1167. https://doi.org/10.1210/endo.141.3.7346

52. Vaccari S, Latini S, Barberi M, Teti A, Stefanini M, Canipari R (2006) Characterization and expression of different pituitary adenylate cyclase-activating polypeptide/ vasoactive intestinal polypeptide receptors in rat ovarian follicles. J Endocrinol 191(1):287-299. https://doi.org/10.1677/joe.1.06470

53. Koh PO, Kwak SD, Kim HJ, Roh G, Kim JH, Kang SS, Choi WS, Cho GJ (2003) Expression patterns of pituitary adenylate cyclase activating polypeptide and its type I receptor mRNAs in the rat placenta. Mol Reprod Dev 64(1):2731. https://doi.org/10.1002/mrd.10221

54. Guidone G, Müller D, Vogt K, Mukhopadhyay AK (2002) Characterization of VIP and PACAP receptors in cultured rat penis corpus cavernosum smooth muscle cells and their interaction with guanylate cyclase-B receptors. Regul Pept 108(2):63-72 https://doi.org/10.1016/S0167-0115(02)00107-6

55. Li M, Funahashi H, Mbikay M, Shioda S, Arimura A (2004) Pituitary adenylate cyclase activating polypeptide-mediated intracrine signaling in the testicular germ cells. Endocrine 23(1):59-75. https://doi.org/10.1385/endo:23:1:59

56. Mazzocchi G, Malendowicz LK, Rebuffat P, Gottardo L, Nussdorfer GG (2002) Expression and function of vasoactive intestinal peptide, pituitary adenylate cyclase-activating polypeptide, and their receptors in the human adrenal gland. J Clin Endocrinol Metabol 87(6):2575-2580

57. Portela-Gomes GM, Lukinius A, Ljungberg O, Efendic S, Ahrén B, AbdelHalim SM (2003) PACAP is expressed in secretory granules of insulin and glucagon cells in human and rodent pancreas: evidence for generation of CAMP compartments uncoupled from hormone release in diabetic islets. Regul Pept 113(1):31-39 https://doi.org/10.1016/S0167-0115(02)00295-1

58. Girard BM, Tooke K, Vizzard MA (2017) PACAP/receptor system in urinary bladder dysfunction and pelvic pain following urinary bladder inflammation or stress. Front Syst Neurosci 11(90):1-23

59. Luts A, Uddman R, Alm R, Basterra J, Sundler F (1993) Peptide-containing nerve fibers in human airways: distribution and coexistence pattern. Int Arch Allergy Immunol 101(1):52-60

60. Sundler F, Ekblad E, Absood A, Håkanson R, Köves K, Arimura A (1992) Pituitary adenylate cyclase activating peptide: a novel vasoactive intestinal peptide-like neuropeptide in the gut. Neuroscience 46(2):439-454 https:// doi.org/10.1016/0306-4522(92)90064-9

61. Abad C, Martinez C, Leceta J, Juarranz MG, Delgado M, Gomariz RP (2002) Pituitary adenylate-cyclase-activating polypeptide expression in the immune system. Neuroimmunomodulation 10(3):177-186

62. Tokuda N, Arudchelvan Y, Sawada T, Adachi Y, Fukumoto T, Yasuda M, Sumida H, Shioda S, Fukuda T, Arima A, Kubota S (2006) PACAP receptor (PAC1-R) expression in rat and rhesus monkey Thymus. Ann N Y Acad Sci 1070(1):581-585. https://doi.org/10.1196/annals.1317.085

63. Ny L, Larsson B, Alm P, Ekström P, Fahrenkrug J, Hannibal J, Andersson KE (1995) Distribution and effects of pituitary adenylate cyclase activating peptide in cat and human lower oesophageal sphincter. Br J Pharmacol 116(7):2873-2880

64. Cardell Lars O, Hjert O, Uddman R (1997) The induction of nitric oxidemediated relaxation of human isolated pulmonary arteries by PACAP. Br J Pharmacol 120(6):1096-1100. https://doi.org/10.1038/sj.bjp.0700992

65. Martin F, Baeres M, Møller M (2004) Origin of PACAP-immunoreactive nerve fibers innervating the Subarachnoidal blood vessels of the rat brain. J Cereb Blood Flow Metab 24(6):628-635. https://doi.org/10.1097/01.wcb.0000121234.42748.f6

66. Filipsson K, Tornøe K, Holst J, Ahrén B (1997) Pituitary adenylate cyclaseactivating polypeptide stimulates insulin and glucagon secretion in humans*. J Clin Endocrinol Metab 82(9):3093-3098

67. Borboni P, Porzio O, Pierucci D, Cicconi S, Magnaterra R, Federici M, Sesti G, Lauro D, D Agata V, Cavallaro S, LNJL M (1999) Molecular and functional characterization of pituitary adenylate cyclase-activating polypeptide (PACAP-38)/vasoactive intestinal polypeptide receptors in pancreatic $\beta$-cells and effects of PACAP-38 on components of the insulin secretory System 1. Endocrinology 140(12):5530-5537

68. Gottschall PE, Tatsuno I, Miyata A, Arimura A (1990) Characterization and distribution of binding sites for the hypothalamic peptide, pituitary adenylate cyclase-activating polypeptide*. Endocrinology 127(1):272-277 
69. Busto R, Prieto JC, Bodega G, Zapatero J, Carrero I (2000) Immunohistochemical localization and distribution of VIP/PACAP receptors in human lung. Peptides 21(2):265-269 https://doi.org/10.1016/S01969781(99)00202-8

70. Zeng N, Kang TAO, Lyu RM, Wong H, Wen YI, Walsh John H, Sachs G, Pisegna Joseph R (1998) The pituitary adenylate cyclase activating polypeptide type 1 receptor (PAC1-R) is expressed on gastric ECL cells: evidence by immunocytochemistry and RT-PCR. Ann N Y Acad Sci 865(1): 147-156. https://doi.org/10.1111/j.1749-6632.1998.tb11173.x

71. Fukushima Y, Hikichi H, Mizukami K, Nagayama T, Yoshida M, Suzuki-Kusaba M, Hisa H, Kimura T, Satoh S (2001) Role of endogenous PACAP in catecholamine secretion from the rat adrenal gland. Am J Phys Regul Integr Comp Phys 281(5):R1562-R1567. https://doi.org/10.1152/ajpregu.2001.281.5.R1562

72. Diané A, Nikolic N, Rudecki AP, King SM, Bowie DJ, Gray SL (2014) PACAP is essential for the adaptive thermogenic response of brown adipose tissue to cold exposure. J Endocrinol 222(3):327-339. https://doi.org/10.1530/joe-14-0316

73. Gray SL, Cummings KJ, Jirik FR, Sherwood NM (2001) Targeted disruption of the pituitary adenylate cyclase-activating polypeptide gene results in early postnatal death associated with dysfunction of lipid and carbohydrate metabolism. Mol Endocrinol 15(10):1739-1747

74. Hamelink C, Tjurmina O, Damadzic R, Young WS, Weihe E, Lee H-W, Eiden LE (2002) Pituitary adenylate cyclase-activating polypeptide is a sympathoadrenal neurotransmitter involved in catecholamine regulation and glucohomeostasis. Proc Natl Acad Sci 99(1):461-466. https://doi.org/10. 1073/pnas.012608999

75. Jamen F, Persson K, Bertrand G, Rodriguez-Henche N, Puech R, Bockaert J, Ahrén B, Brabet $P$ (2000) $P A C_{1}$ receptor-deficient mice display impaired insulinotropic response to glucose and reduced glucose tolerance. J Clin Investig 105(9):1307-1315

76. Lutz-Bucher B, Monnier D, Koch B (1996) Evidence for the presence of receptors for pituitary adenylate cyclase-activating polypeptide in the neurohypophysis that are positively coupled to cyclic AMP formation and Neurohypophyseal hormone secretion. Neuroendocrinology 64(2):153-161

77. Hautmann M, Friis UG, Desch M, Todorov V, Castrop H, Segerer F, Otto C, Schütz G, Schweda F (2007) Pituitary adenylate cyclase-activating polypeptide stimulates renin secretion via activation of PAC1 receptors. J Am Soc Nephrol 18(4):1150-1156. https://doi.org/10.1681/asn.2006060633

78. Nemetz N, Abad C, Lawson G, Nobuta H, Chhith S, Duong L, Tse G, Braun J, Waschek JA (2008) Induction of colitis and rapid development of colorectal tumors in mice deficient in the neuropeptide PACAP. Int J Cancer 122(8): 1803-1809. https://doi.org/10.1002/ijc.23308

79. Babai N, Atlasz T, Tamás A, Reglodi D, Tóth G, Kiss P, Gábriel R (2005) Degree of damage compensation by various pacap treatments in monosodium glutamate-induced retinal degeneration. Neurotox Res 8(3): 227-233. https://doi.org/10.1007/bf03033976

80. Chen Y, Samal B, Hamelink CR, Xiang CC, Chen Y, Chen M, Vaudry D, Brownstein MJ, Hallenbeck JM, Eiden LE (2006) Neuroprotection by endogenous and exogenous PACAP following stroke. Regul Pept 137(1):419 https://doi.org/10.1016/j.regpep.2006.06.016

81. Dejda A, Seaborn T, Bourgault S, Touzani O, Fournier A, Vaudry $H$, Vaudry D (2011) PACAP and a novel stable analog protect rat brain from ischemia: insight into the mechanisms of action. Peptides 32(6):1207-1216 https://doi. org/10.1016/j.peptides.2011.04.003

82. László E, Kiss P, Horváth G, Szakály P, Tamás A, Reglödi D (2014) The effects of pituitary adenylate cyclase activating polypeptide in renal ischemia/reperfusion. Acta Biol Hung 65(4):369-378. https://doi.org/10.1556/ABiol.65.2014.4.1

83. Lazarovici $P$, Cohen G, Arien-Zakay H, Chen J, Zhang C, Chopp M, Jiang H (2012) Multimodal neuroprotection induced by PACAP38 in oxygenglucose deprivation and middle cerebral artery occlusion stroke models. J Mol Neurosci 48(3):526-540. https://doi.org/10.1007/s12031-012-9818-1

84. Muzzi M, Buonvicino D, De Cesaris F, Chiarugi A (2017) Acute and chronic triptan exposure neither alters rodent cerebral blood flow nor worsens ischemic brain injury. Neuroscience 340:1-7. https://doi.org/10.1016/j. neuroscience.2016.10.046

85. Ohtaki H, Nakamachi T, Dohi K, Aizawa Y, Takaki A, Hodoyama K, Yofu S, Hashimoto H, Shintani N, Baba A, Kopf M, Iwakura Y, Matsuda K, Arimura A, Shioda S (2006) Pituitary adenylate cyclase-activating polypeptide (PACAP) decreases ischemic neuronal cell death in association with IL-6. Proc Natl Acad Sci 103(19):7488-7493. https://doi.org/10.1073/pnas.0600375103

86. Reglodi D, Somogyvari-Vigh A, Vigh S, Kozicz T, Arimura A (2000) Delayed systemic administration of PACAP38 is neuroprotective in transient middle cerebral artery occlusion in the rat. Stroke 31(6):1411-1417. https://doi.org/ 10.1161/01.str.31.6.1411

87. Reglodi D, Tamás A, Somogyvári-Vigh A, Szántó Z, Kertes E, Lénárd L, Arimura A, Lengvári I (2002) Effects of pretreatment with PACAP on the infarct size and functional outcome in rat permanent focal cerebral ischemia. Peptides 23(12): 2227-2234 https://doi.org/10.1016/S0196-9781(02)00262-0

88. Vaczy A, Reglodi D, Somoskeoy T, Kovacs K, Lokos E, Szabo E, Tamas A, Atlasz T (2016) The protective role of PAC1-receptor agonist Maxadilan in BCCAO-induced retinal degeneration. J Mol Neurosci 60(2):186-194. https:// doi.org/10.1007/s12031-016-0818-4

89. Reglodi D, Vaczy A, Rubio-Beltran E, MaassenVanDenBrink A (2018) Protective effects of PACAP in ischemia. J Headache Pain 19(1):19. https:// doi.org/10.1186/s10194-018-0845-3

90. Botz B, Bölcskei K, Kereskai L, Kovács M, Németh T, Szigeti K, Horváth I, Máthé $D$, Kovács N, Hashimoto H, Reglődi D, Szolcsányi J, Pintér E, Mócsai $A$, Helyes Z (2014) Differential regulatory role of pituitary adenylate cyclaseactivating polypeptide in the serum-transfer arthritis model. Arthritis Rheumatol 66(10):2739-2750. https://doi.org/10.1002/art.38772

91. Warren JB, Larkin SW, Coughlan M, Kajekar R, Williams TJ (1992) Pituitary adenylate cyclase activating polypeptide is a potent vasodilator and oedema potentiator in rabbit skin in vivo. Br J Pharmacol 106(2):331-334. https://doi.org/10.1111/j.1476-5381.1992.tb14336.x

92. Svensjö E, Saraiva EM, Amendola RS, Barja-Fidalgo C, Bozza MT, Lerner EA, Teixeira MM, Scharfstein J (2012) Maxadilan, the Lutzomyia longipalpis vasodilator, drives plasma leakage via PAC1-CXCR1/2-pathway. Microvasc Res 83(2):185-193 https://doi.org/10.1016/j.mvr.2011.10.003

93. Watanabe J, Nakamachi T, Matsuno R, Hayashi D, Nakamura M, Kikuyama S, Nakajo S, Shioda S (2007) Localization, characterization and function of pituitary adenylate cyclase-activating polypeptide during brain development Peptides 28(9):1713-1719 https://doi.org/10.1016/j.peptides.2007.06.029

94. Ghzili $H$, Grumolato L, Thouënnon E, Tanguy $Y$, Turquier V, Vaudry H, Anouar $Y$ (2008) Role of PACAP in the physiology and pathology of the sympathoadrenal system. Front Neuroendocrinol 29(1):128-141 https://doi. org/10.1016/j.yfrne.2007.10.001

95. Lezak KR, Roelke E, Harris OM, Choi I, Edwards S, Gick N, Cocchiaro G, Missig G, Roman CW, Braas KM, Toufexis DJ, May V, Hammack SE (2014) Pituitary adenylate cyclase-activating polypeptide (PACAP) in the bed nucleus of the stria terminalis (BNST) increases corticosterone in male and female rats. Psychoneuroendocrinology 45:11-20 https://doi.org/10.1016/j.psyneuen. 2014.03.007

96. King SB, Toufexis DJ, Hammack SE (2017) Pituitary adenylate cyclase activating polypeptide (PACAP), stress, and sex hormones. Stress 20(5):465475. https://doi.org/10.1080/10253890.2017.1336535

97. Ressler KJ, Mercer KB, Bradley B, Jovanovic T, Mahan A, Kerley K, Norrholm SD, Kilaru V, Smith AK, Myers AJ, Ramirez M, Engel A, Hammack SE, Toufexis D, Braas KM, Binder EB, May V (2011) Post-traumatic stress disorder is associated with PACAP and the PAC1 receptor. Nature 470:492. https://doi. org/10.1038/nature09856

98. Tajti J, Tuka B, Botz B, Helyes Z, Vecsei L (2015) Role of pituitary adenylate cyclase-activating polypeptide in nociception and migraine. CNS Neurol Disord Drug Targets 14(4):540-553 https://doi.org/10.2174/ 1871527314666150429114234

99. Sándor K, Bölcskei K, McDougall JJ, Schuelert N, Reglodi D, Elekes K, Petho G, Pintér E, Szolcsányi J, Helyes Z (2009) Divergent peripheral effects of pituitary adenylate cyclase-activating polypeptide-38 on nociception in rats and mice. Pain 141(1):143-150. https://doi.org/10.1016/j.pain.2008.10.028

100. Amin FM, Schytz HW (2018) Transport of the pituitary adenylate cyclaseactivating polypeptide across the blood-brain barrier: implications for migraine. J Headache Pain 19(1):35. https://doi.org/10.1186/s10194-018-0861-3

101. Edvinsson L, Tajti J, Szalárdy L, Vécsei L (2018) PACAP and its role in primary headaches. J Headache Pain 19(1):21. https://doi.org/10.1186/s10194-018-0852-4

102. Vollesen ALH, Ashina M (2017) PACAP38: emerging drug target in migraine and cluster headache. Headache: J Head Face Pain 57(S2):56-63. https://doi. org/10.1111/head.13076

103. Bacchelli E, Cainazzo MM, Cameli C, Guerzoni S, Martinelli A, Zoli M, Maestrini E, Pini LA (2016) A genome-wide analysis in cluster headache points to neprilysin and PACAP receptor gene variants. J Headache Pain 17(1):114. https://doi.org/10.1186/s10194-016-0705-y

104. Guo S, Petersen AS, Schytz HW, Barløse M, Caparso A, Fahrenkrug J, Jensen $\mathrm{RH}$, Ashina M (2017) Cranial parasympathetic activation induces autonomic symptoms but no cluster headache attacks. Cephalalgia 38 (8):1418-1428 
105. Tuka B, Helyes Z, Markovics A, Bagoly T, Szolcsányi J, Szabó N, Tóth E, Kincses ZT, Vécsei L, Tajti J (2013) Alterations in PACAP-38-like immunoreactivity in the plasma during ictal and interictal periods of migraine patients. Cephalalgia 33(13):1085-1095. https://doi.org/10.1177/ 0333102413483931

106. Tuka B, Szabó N, Tóth E, Kincses ZT, Párdutz Á, Szok D, Körtési T, Bagoly T, Helyes Z, Edvinsson L, Vécsei L, Tajti J (2016) Release of PACAP-38 in episodic cluster headache patients - an exploratory study. J Headache Pain 17(1):69. https://doi.org/10.1186/s10194-016-0660-7

107. Hou L, Wan D, Dong Z, Tang W, Han X, Li L, Yang F, Yu S (2016) Pituitary adenylate cyclase-activating polypeptide expression in peripheral blood mononuclear cells of migraineurs. Cell Biosci 6:40. https://doi.org/10.1186/ s13578-016-0106-6

108. Zagami AS, Edvinsson L, Goadsby PJ (2014) Pituitary adenylate cyclase activating polypeptide and migraine. Ann Clin Transl Neurol 1(12):10361040. https://doi.org/10.1002/acn3.113

109. Schytz HW, Birk S, Wienecke T, Kruuse C, Olesen J, Ashina M (2009) PACAP38 induces migraine-like attacks in patients with migraine without aura. Brain 132(1):16-25. https://doi.org/10.1093/brain/awn307

110. Ashina M, Hansen JM, á Dunga BO, Olesen J (2017) Human models of migraine - short-term pain for long-term gain. Nat Rev Neurol 13:713. https://doi.org/10.1038/nrneurol.2017.137

111. Bergerot A, Holland PR, Akerman S, Bartsch T, Ahn AH, MaassenVanDenBrink A, Reuter U, Tassorelli C, Schoenen J, Mitsikostas DD, VanDenMaagdenberg AMJM, Goadsby PJ (2006) Animal models of migraine: looking at the component parts of a complex disorder. Eur J Neurosci 24(6):1517-1534 https://doi.org/10.1111/j.1460-9568.2006.05036.x

112. Birk S, Sitarz J, Petersen KA, Oturai PS, Kruuse C, Fahrenkrug J, Olesen J (2007) The effect of intravenous PACAP38 on cerebral hemodynamics in healthy volunteers. Regul Pept 140(3):185-191 https://doi.org/10.1016/..regpep.2006.12.010

113. Amin FM, Asghar MS, Guo S, Hougaard A, Hansen AE, Schytz HW, RJvd G, de PJH K, HBW L, Olesen J, Ashina M (2012) Headache and prolonged dilatation of the middle meningeal artery by PACAP38 in healthy volunteers. Cephalalgia 32(2):140-149. https://doi.org/10.1177/ 0333102411431333

114. Amin FM, Hougaard A, Schytz HW, Asghar MS, Lundholm E, Parvaiz Al, de Koning PJH, Andersen MR, Larsson HBW, Fahrenkrug J, Olesen J, Ashina M (2014) Investigation of the pathophysiological mechanisms of migraine attacks induced by pituitary adenylate cyclase-activating polypeptide-38 Brain 137(3):779-794. https://doi.org/10.1093/brain/awt369

115. Chan KY, Baun M, de Vries R, van den Bogaerdt AJ, Dirven CM, Danser AH, Jansen-Olesen I, Olesen J, Villalon CM, MaassenVanDenBrink A, Gupta S (2011) Pharmacological characterization of VIP and PACAP receptors in the human meningeal and coronary artery. Cephalalgia 31(2):181-189. https:// doi.org/10.1177/0333102410375624

116. Amin FM, Hougaard A, Magon S, Asghar MS, Ahmad NN, Rostrup E, Sprenger T, Ashina M (2016) Change in brain network connectivity during PACAP38-induced migraine attacks A resting-state functional MRI study. Neurology 86(2):180-187. https://doi.org/10.1212/wnl.0000000000002261

117. Guo S, Vollesen ALH, Olesen J, Ashina M (2016) Premonitory and nonheadache symptoms induced by CGRP and PACAP38 in patients with migraine. Pain 157(12):2773-2781. https://doi.org/10.1097/j.pain. 0000000000000702

118. Guo S, Vollesen ALH, Hansen YBL, Frandsen E, Andersen MR, Amin FM, Fahrenkrug J, Olesen J, Ashina M (2017) Part II: biochemical changes after pituitary adenylate cyclase-activating polypeptide-38 infusion in migraine patients. Cephalalgia 37(2):136-147. https://doi.org/10.1177/ 0333102416639517

119. Hassan M, Refai E, Andersson M, Schnell P-O, Jacobsson H (1994) In vivo dynamical distribution of ${ }^{131} \mathrm{IVIP}$ in the rat studied by gamma-camera. Nucl Med Biol 21(6):865-872. https://doi.org/10.1016/0969-8051(94)90166-X

120. Boni L, Ploug KB, Olesen I, Jansen-Olesen I, Gupta S (2009) The in vivo effect of VIP, PACAP-38 and PACAP-27 and mRNA expression of their receptors in rat middle meningeal artery. Cephalalgia 29(8):837-847. https:// doi.org/10.1111/j.1468-2982.2008.01807.x

121. Akerman S, Goadsby PJ (2015) Neuronal PAC receptors mediate delayed activation and sensitization of trigeminocervical neurons: relevance to migraine. Sci Transl Med 7(308):308ra157. https://doi.org/10.1126/ scitransImed.aaa7557
122. Han X, Ran Y, Su M, Liu Y, Tang W, Dong Z, Yu S (2017) Chronic changes in pituitary adenylate cyclase-activating polypeptide and related receptors in response to repeated chemical dural stimulation in rats. Mol Pain 13:1-10

123. Hoffmann J, Martins-Oliveira M, Akerman S, Supronsinchai W, Xu C, Goadsby PJ (2016) PAC-1 receptor antibody modulates nociceptive trigeminal activity in rat. Cephalalgia 36(1S):141-141

124. Baun M, Pedersen MHF, Olesen J, Jansen-Olesen I (2012) Dural mast cell degranulation is a putative mechanism for headache induced by PACAP-38. Cephalalgia 32(4):337-345. https://doi.org/10.1177/0333102412439354

125. Bhatt DK, Gupta S, Olesen J, Jansen-Olesen I (2014) PACAP-38 infusion causes sustained vasodilation of the middle meningeal artery in the rat: possible involvement of mast cells. Cephalalgia 34(11):877-886. https://doi. org/10.1177/0333102414523846

126. Ottosson A, Edvinsson L (1997) Release of histamine from Dural mast cells by substance $P$ and calcitonin gene-related peptide. Cephalalgia 17(3):166174. https://doi.org/10.1046/j.1468-2982.1997.1703166.x

127. Study to Evaluate the Efficacy and Safety of AMG 301 in Migraine Prevention. https://clinicaltrials.gov/ct2/show/NCT03238781. Accessed 02 May 2018.

128. ALD1910 - migraine prevention. alderbio.com. https://www.alderbio.com/ pipeline/ald1910/. Accessed 19 May 2018.

129. Martínez C, Juarranz Y, Abad C, Arranz A, Miguel BG, Rosignoli F, Leceta J, Gomariz RP (2005) Analysis of the role of the PAC receptor in neutrophil recruitment, acute-phase response, and nitric oxide production in septic shock. J Leukoc Biol 77(5):729-738. https://doi.org/10.1189/jb.0704432

130. Chang CL, Donaghy M, Poulter N (1999) Migraine and stroke in young women: case-control study. BMJ : Br Med J 318(7175):13-18. https://doi.org/ 10.1136/bmj.318.7175.13

131. Etminan M, Takkouche B, Isorna FC, Samii A (2005) Risk of ischaemic stroke in people with migraine: systematic review and meta-analysis of observational studies. BMJ : Br Med J 330(7482):63-63. https://doi.org/10. 1136/bmj.38302.504063.8F

132. Schurks M, Rist PM, Bigal ME, Buring JE, Lipton RB, Kurth T (2009) Migraine and cardiovascular disease: systematic review and meta-analysis. BMJ: $\mathrm{Br}$ Med J 339:b3914

133. Spector JT, Kahn SR, Jones MR, Jayakumar M, Dalal D, Nazarian S (2010) Migraine headache and ischemic stroke risk: an updated meta-analysis. Am J Med 123(7):612-624. https://doi.org/10.1016/j.amjmed.2009.12.021

134. Deen M, Correnti E, Kamm K, Kelderman T, Papetti L, Rubio-Beltran E, Vigneri S, Edvinsson L, Maassen Van Den Brink A, European Headache Federation School of Advanced S (2017) Blocking CGRP in migraine patients - a review of pros and cons. J Headache Pain 18(1):96. https://doi.org/10 1186/s10194-017-0807-1

135. MaassenVanDenBrink A, Meijer J, Villalón CM, Ferrari MD (2016) Wiping out CGRP: potential cardiovascular risks. Trends Pharmacol Sci 37(9):779-788. https://doi.org/10.1016/j.tips.2016.06.002

136. Mitsikostas DD, Reuter U (2017) Calcitonin gene-related peptide monoclonal antibodies for migraine prevention: comparisons across randomized controlled studies. Curr Opin Neurol 30(3):272-280. https://doi.org/10.1097/ wco.0000000000000438

\section{Ready to submit your research? Choose BMC and benefit from:}

- fast, convenient online submission

- thorough peer review by experienced researchers in your field

- rapid publication on acceptance

- support for research data, including large and complex data types

- gold Open Access which fosters wider collaboration and increased citations

- maximum visibility for your research: over $100 \mathrm{M}$ website views per year

At BMC, research is always in progress.

Learn more biomedcentral.com/submissions 